\title{
RAPID ACTIVATION ANALYSIS OF TRACE VANADIUM IN TISSUE USING 3.8-MINUTE VANADIUM-52
}

\author{
DAVID G. KAISER* AND W. WAYNE MEINKE
}

Department of Chemistry, University of Michigan, Ann Arbor, Michigan (U.S.A.)

(Received January 7 th, 1963 )

The determination of trace quantities of vanadium has been handicapped by insensitive methods of analysis. Most of the recent methods are based on the formation of a color complex and quantitative spectrophotometric determination. Activation analysis, however, which holds great promise for trace analysis of biological systems, ${ }^{1}$ offers a procedure which is sensitive to submicrogram amounts of vanadium. This is especially helpful in biological analysis where vanadium is present in amounts undetectable by standard procedures.

Because the facilities available at this laboratory permitted short irradiations in the Ford Nuclear Reactor of the University of Michigan, rapid chemical separation in the hot lab area, and continuous $\gamma$-ray spectral analysis with a roo-channel analyzer, considerable attention has been focused on short-lived radioisotopes. Utilizing activation analysis procedures with radiochemistry, BROWNIEE AND MFINKE 2 have determined the vanadium content in crude oils, while FUKAI AND MEINKE ${ }^{3}$ analyzed ashes of marine organisms for their vanadium content. BENSON 4 has applied this technique to vanadium compounds pre-separated on chromatographic paper, but in doing so has acquired the problems of reagent blanks which are usually eliminated in activation analysis.

Spectroscopic investigations conducted by Guelbenzu $c t$ al. ${ }^{5}$ placed the vanadium content of rat livers below the microgram level. The purpose of this investigation was to establish a lower limit for vanadium content in rat liver tissue or to determine it at the submicrogram level.

\section{Apparatus}

EXPERIMENTAL

Samples were irradiated in polyethylene screw-cap rabbits in the pneumatic tube system of the Ford Nuclear Reactor of the University of Michigan. This system permitted irradiations at thermal neutron fluxes of about $\mathrm{IO}^{12} \mathrm{n} / \mathrm{cm}^{2} / \mathrm{sec}$ (when the reactor was operating at full power of I megawatt) and delivery to a hood in the neighboring Michigan Memorial Phoenix Laboratory within $3 \mathrm{sec}$ after the end of irradiation. Samples were then worked up chemically and were measured by a $3^{\prime \prime} \times 3^{\prime \prime} \mathrm{NaI}$ (TI) crystal coupled with a special roo-channel pulse-height analyzer with duplicate memories. This equipment has been described in detail tlsewhere ${ }^{0-8}$.

- Present address: The Upjohn Company, Kalamazoo. Michigan. 
Preparation of animals and tissue

Holtzman* albino male rats weighing between 350 and $400 \mathrm{~g}$ were used in this study. They were maintained on Rockland Rat Diet** and had free access to drinking water. The livers were surgically removed, weighed, allowed to air-dry at room temperature for $24 \mathrm{~h}$ and then reweighed. They were placed in envelopes prepared from $0.1 \mathrm{~mm}$ thick polyethylene film, which were closed by heat sealing. The sealed sample was then irradiated in a "rabbit" along with suitable monitoring foils for a period of ro min at full power.

\section{Radiochemical separation}

While the sample was being irradiated a nickel crucible was prepared containing vanadium-48 tracer, ro mg of vanadium carrier, and $10 \mathrm{mg}$ of copper holdback carrier. Three sodium hydroxide pellets were added and the solution was heated almost to dryness. I'wo minutes before the end of the irradiation, $10 \mathrm{~g}$ of sodium peroxide were added to the crucible and melted.

The irradiated sample was then fused in this melt for $1 \mathrm{~min}$ (cAcron). A cover must be used on the crucible since the reaction may be quite violent. The outside of the crucible was then cooled by dropping it into a beaker of cold water and the melt made to soliclify in a thin readily dissolvable coating by manipulation of the crucible. The melt was then dissolved by immersion into $50 \mathrm{ml}$ of water followed by the addition of $42 \mathrm{ml}$ of conceritrated hydrochloric acid. Ten grams of tartaric acid were added and $\mathrm{H}_{2} \mathrm{~S}$ gas was bubbled into the solution. The solution was filtered and $10 \mathrm{ml}$ of cupferron solution ( $6 \%$ aqueous) were added to the filtrate. This filtrate was extracted with ro $\mathrm{ml}$ of chloroform for $\mathrm{I}$ min. The organic layer was collected and counted with the roo-

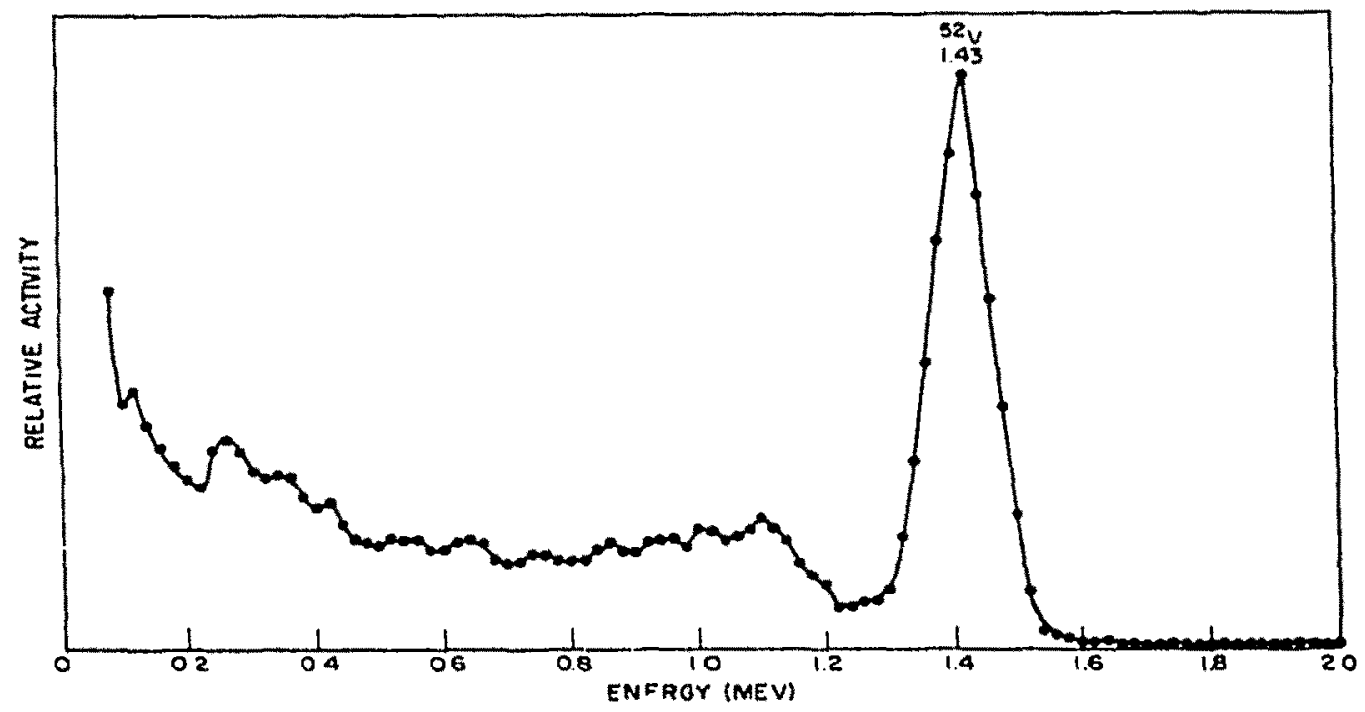

Fig. 1. $\gamma$-Ray spectram of vanadium fraction separated from rat liver tissue (s min after removal frum reactur).

* Holtrmar Company. Maclisen i. Wisconsin.

* A proluct of Rockland liarms, New City. N.Y.: manufactured by A.1:. Stalcy Manufacturing Company, Chicago 27 . Illinois. 
channel analyzer. The entire procedure could be completed in 5 min with an average vanadium recovery of about $40-45 \%$.

\section{Activity determination}

Linearity of the measurement system was established by the use of $137 \mathrm{Cs}$ and $00 \mathrm{Co}$ standards. Spectra were obtained in the $0-2 \mathrm{MeV}$ energy range as shown in Figs. I and 2. The amount of vanadium-52 was determined from the area under the $1.43 \mathrm{MeV}$ photopeak, while the correction for chemical yield was made by measuring recovery of long-lived tracer vanadium- 48 utilizing the $0.99 \mathrm{MeV}$ photopeak after the shorterlived peak had decayed out.

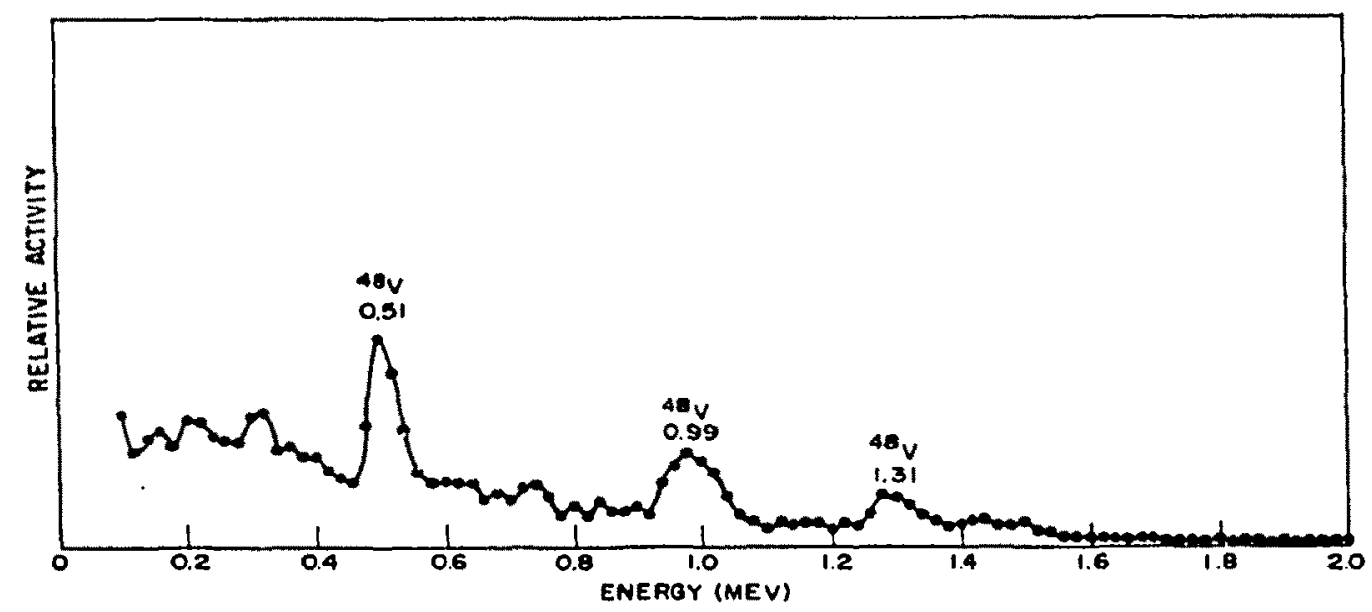

Fig. 2. $\gamma$-Ray spectrum of vanadium fraction separated from rat liver tissue $(40$ min after removal from reactor).

\section{Monitoring procedures}

Gold foils weighing between 0.2 and $0.3 \mathrm{mg}$ were wrapped in plastic envelopes and taped to the inside of the cap of the rabbit. Following irradiation the foils were dissolved in $4 \mathrm{ml}$ of acjua regia and diluted to $10 \mathrm{ml}$ with distilled water. An aliquot of this solution was placed in a test tube and counted with a well-type scintillation counter. Comparison with other measurements made with calibrated gold foils permitted normalization of all irradiations to a neutron flux of I. Iol2.

\section{RESULTS AND DISCUSSION}

By this procedure, values for the normally occurring vanadium concentrations in rat liver tissue were obtained, as shown in Table I. Alt hough these values show a variation of greater than a factor of two, they do establish an order of magnitude.

Most spectroscopic procedures are not sufficiently sensitive to detect these levels in complex biological systems. Utilization of activation analysis, i.e., the short-lived vanadium-52, reduces the possibility of prolonged radioactive contamination, provides a sensitive analytical method and allows rapid analysis of numerous samples. The use of long-lived vanadium- 48 for calculating chemical yield offers the added advantage of one procedure yiclding two results, e.g.. amount of vanadium-52 and yield 
TABLE: I

ACTIVATION ANALYSIS FOR VANAUIUM IN KAT LIVIER TISSUE USING VANADIUM-52

\begin{tabular}{|c|c|c|c|c|}
\hline $\begin{array}{l}\text { Animal } \\
\text { ntcmber }\end{array}$ & $\begin{array}{c}\text { I.ife } \\
\text { teight } \\
(g)\end{array}$ & $\begin{array}{l}\text { riresh } \\
\text { liver } \\
\text { weight } \\
(\mathrm{g})\end{array}$ & $\begin{array}{l}\text { Yicld of } \\
\text { separalinn } \\
\text { procedure } \\
(\%)\end{array}$ & $\begin{array}{c}\text { Vanadizum found } \\
\text { in livers } \\
\text { ro- glg } \\
\text { fresh tissue }\end{array}$ \\
\hline 1 & $35^{8.5}$ & r I.61 & $3^{8.7}$ & 3.2 \\
\hline 2 & 378.0 & 1.9 .0 .1 & 4.5 .4 & 1.4 \\
\hline 3 & 378.4 & 11.81 & 40.1 & 2.8 \\
\hline 4 & $367 \cdot 3$ & 13.15 & .10 .9 & 3.1 \\
\hline 5 & 32.1 .1 & 12.43 & .2 .4 & 2.0 \\
\hline
\end{tabular}

- Corructed to neutron flux of $1 \cdot 10^{12} \mathrm{n} / \mathrm{cm}^{2} / \mathrm{sec}^{2}$

correction from the isclated vanadium-48. Where possible it would be preferable to work with smaller samples becatuse extreme care is required when at large irradiated sample is fused in sodium peroxide.

This work was supported in part by the Michigan Memorial Phoenix Project and the U.S. Atomic lincrgy Commission. Thanks are due to Professor H. J. Gomblikg, C. W. RrCKER, and the staff of the Ford Nuclear Reactor for their help in making the irradiations.

\section{SUMMAR:}

Submicrogram amounts of vanadium in rat liver tissuc have been analyod by rapid activation analysis. $\Lambda_{5-m i n}$ radiochenical separation coupled with $\gamma$-ray spectrometry permitted utilization of the $3.8-m i n$ vanadium-52 radinisotope. With this procedure the lower limit of detection at a thermal neutron flux of $10^{12} \mathrm{n} / \mathrm{cm}^{2} / \mathrm{sec}$ was about $3 \cdot 10^{-9} \mathrm{~g}$ of vanalium.

\section{RISSUMI:}

1)e submicropuantites de vanadium $\left(3 \cdot 10^{-v} \mathrm{~g}\right)$ dans des tissus biologicpues (foie de rat) ont pu etre déterminées rapidement par activation. Une separation racliochimique de 5 min, combinće avec une spectromstric aux rayons-x, permet l'utilisation du raclioisotope vanaclium-52 (3.8 mirn).

\section{ZUSAMMENINASSUNG}

Vanadiun wurcle in Gewelo von Rattenlebern mit llilfe der Neutronenalstivierungyanalyse bestimmt. Jie Prolicn wurclen leurze Zeit bestrihlt, innerhall, von 5 Mlinuten radiochemisch getrennt, und mit cinem $\gamma-s_{p}$ cktrometer die Aktivitit des Vanadium $-52\left(t_{1 / 2}=3.8 \mathrm{~min}\right)$ bestimmt. Die Nachweisgrenze lag bei einem thernischen Neutronenfluss von $10^{12} / \mathrm{cm}^{2} / \mathrm{sec} \mathrm{bei} 3 \cdot 10^{-0} \mathrm{~g}$ Vinadium.

\section{RIFERENCIS}

13. A. l.oviki bGi: AND A. A. Smales, in Methods of Biochemical Analysis, Vol. V., Interscience, New Yorle. 10.57 , p. 225 .

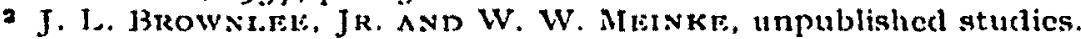

IR. FukAI ANd W. IV, Mrinke, Limmol. Oceamog., I (1002) iso.

A. A. 13 Esson, Proc. Sicond Intern. Conf. Peaceful Uses At. Energy. Geneva, xy58. 1Maper 858 , p. $1-13$.

5 M. D. Gurlbenzu, J. M. I.. Azcona And A. S. Ruiz, Rev. Espan. Fisiol., 7 (1951) 74.

- W. W. MEINKL, Nucleonics, $17 / 9(1959) 86$.

7 W. W. MeIN KI. U, S. At. Encrgy Comm. Rep. AECU 364I, November 1957.

W. W. Mistak. U, S. At. Energy Comm. Rep. AlECU 3887, November 1958. 